\title{
Foraging behavior of the Greater White-fronted Goose (Anser albifrons) wintering at Shengjin Lake: diet shifts and habitat use
}

Yanguang Fan ${ }^{1,2}$, Lizhi Zhou ${ }^{1,2^{*}}$, Lei Cheng ${ }^{1,2}$, Yunwei Song ${ }^{3}$ and Wenbin $\mathrm{Xu}^{3}$

\begin{abstract}
Background: The habitat use and foraging behaviors of waterbirds are closely related to the distribution and abundance of their food resources. Reductions in food supply can cause waterbirds to shift their habitats and adjust their foraging behaviors to meet their nutritional requirements and increase fitness. Seasonal withdraw of the water levels in the river-connected lakes in the middle and lower Yangtze River floodplain provides abundant food resources for the wintering Greater White-fronted Goose (Anser albifrons). Sedge (Carex) meadows are critical foraging habitats for herbivorous waterbirds in the hydro-fluctuation belt, which changes with hydrological conditions and climate. This study aimed to examine the behavioral responses of the Greater White-fronted Goose to temporal- spatial changes of food availability in the Sedge meadows.

Methods: Fields surveys were carried out at Shengjin Lake from November 2017 to April 2018. According to the phenology of Shengjin Lake, we divided the wintering season into three periods. The food density, minimum temperature, food items, grass height, and number of foraging geese were surveyed, and samples of the foraging behavior were collected. We analyzed the relationship of the foraging behavior and habitat use relative to the food resources, using correlation and linear regression analyses.
\end{abstract}

Results: Along with the temporal-spatial variation and exploitation of food resources, the food abundance and items varied widely among the foraging sites. Over the whole wintering period, the foraging habitat with the highest utilization rate was the meadows, followed by the paddy fields, and then mudflats. Furthermore, the utilization of the meadows showed a bimodal distribution trend, while the paddy fields showed a unimodal trend, and a decreasing trend was seen in the mudflats over the whole wintering period. The results of the generalized linear model showed that the foraging rate was related to the food density and grass height, with a linearly increasing trend during the winter.

Conclusions: With the change of food resources in the three habitats, the habitats used by the Greater White-fronted Geese shifted from meadows in the hydro-fluctuation belt to the paddy fields, and then back to the meadows. The time budget for foraging activities increased correspondingly, and there was an increase in the foraging rate to compensate for food shortages.

Keywords: Foraging behavior, Foraging rate, Food resources, Grass height, Habitat use

*Correspondence: zhoulz@ahu.edu.cn

1 School of Resources and Environmental Engineering, Anhui University, Hefei 230601, China

Full list of author information is available at the end of the article

\section{Background}

Overwintering is a critical and crucial stage in the annual lifecycle of waterbirds (Jing et al. 2017). Food plays an important role during the winter season for many avian species and can affect the physiology of waterbirds (Beerens et al. 2011; Pearse et al. 2011). 
According to the optimal foraging theory, animals always choose the most efficient and advantageous habitat patches for foraging, in order to minimize their costs and maximize their incomes, in the form of energy (Páez et al. 2018). Wintering waterbirds also utilize effective behavior patterns to obtain enough food supplies from their wetland habitats, but these can be affected by both food abundance and availability. Waterbirds must change their wintering habitats and behavior patterns in order to obtain sufficient energy during this period (Holm 2002; Kuwae et al. 2010). For many waterbirds, changes in their food items on a temporal-spatial scale affect the selection of their foraging habitats (Faragó and Hangya 2012) and behaviors (Maheswaran and Rahmani 2001; Recher and Davis 2018).

When accessible, some herbivorous waterbirds efficiently feed on Carex and rice sprouts during different wintering stages. Carex and rice sprouts are highly digestible and readily found in meadows, mudflats, and paddy fields, however, the quantity and quality of Carex changes throughout the wintering period (Xia et al. 2017). It is reported that fiber and lignin content increases with the gradual increase in grass height (Wilmshurst et al. 1995), so waterbirds prefer to feed on slightly taller grass in a suitable range (Zhang et al. 2014). Waterbirds have tradeoffs between the grass height and the degree of digestion, therefore, the grass height is a key factor, which affects the foraging strategies of herbivorous waterbirds and limits their food availability (Durant et al. 2003). The reduction in food availability forces waterbirds to move to new habitats (Toral et al. 2011), such as paddy fields after harvest (Shimada. 2002). If their food availability is reduced, waterbirds will increase their foraging rate and adjust their foraging time (Nolet et al. 2002; Klaassen et al. 2006; Guan et al. 2014). Some external factors such as temperature also directly affect their food items and foraging strategies (Owensmith 2010). In order to meet the energy requirements and obtain enough nutrients, waterbirds assemble in large flocks in wetland habitats, especially lakes with higher productivity ( $\mathrm{Li}$ et al. 2013a). As the capacity of their natural habitats decreases, waterbirds have demonstrated flexible foraging strategies, by foraging in new habitats and changing their foraging behavior (Zheng et al. 2015).

Shengjin Lake, in the middle and lower Yangtze River flood plain, is an important wintering ground for waterbirds on the East Asian-Australasian flyway (Cao and Fox 2009). In recent years, the ecological processes of the wetlands have been seriously disturbed, resulting in changes of the distribution and habitat utilization of the wintering waterbirds (Fox et al. 2011), and adverse effects on their annual life cycles (Zheng et al. 2015).
The Greater White-fronted Goose is a herbivorous waterbird species, breeding in south-central and southeastern Siberia and northern America, with wintering grounds in Japan, South Korea, and south-eastern China (Zhang et al. 2018). Due to the degradation of some lakes in the lower and middle Yangtze River floodplains and implementation of better management measures at Shengjin Lake, the number of Greater White-fronted Geese has been increasing yearly according to the monitoring results at Shengjin Lake. As the waterbirds have a relatively low foraging niche, it is important to understand their behavioral strategies with regard to spatial and temporal variations in their food items, and it would also help to understand the ecological adaptability of the geese and the conservation measures that should be taken for the Greater White-fronted Goose population. This study is mainly focused on the adaptations of Greater White-fronted Goose, due to changes in food resources and habitat. There is large area of Carex in the lake beach depression zones, with fewer human disturbances during the wintering period. The reclaimed lands from marshes, are dominated by paddy fields where rice is grown. The Greater White-fronted Goose chooses rice buds in paddy fields after harvest, but their foraging is frequently interrupted by human activities (Maeda. 2001). Therefore this study focuses on two assumptions: (1) under the influence of spatial and temporal variations of their food supplies in fluctuating zones, when the food items are less palatable, the Greater White-fronted Goose will forage in paddy fields and increase their activity time budgets for foraging, to acquire more food; and (2) there are some key factors influencing the efficiency of feeding, including grass height, food density, and temperature, of which, food density is thought to be the most important factor influencing foraging rates.

\section{Methods \\ Study area}

The study area was located at the upper part of Shengjin Lake $\left(30.25^{\circ}-30.50^{\circ} \mathrm{N}, 116.92^{\circ}-117.25^{\circ} \mathrm{E}\right)$, a shallow lake connected to the Yangtze River on the East AsianAustralasian flyway for birds (Fox et al. 2008; Zhou et al. 2010; Zhang et al. 2015). The region has a humid subtropical monsoon climate, with an average annual temperature of $16.1{ }^{\circ} \mathrm{C}$ and annual precipitation of $1600 \mathrm{~mm}$. There is a clear separation between the rainy and dry seasons: the rainy season is from April to October, when the water level reaches $17.6 \mathrm{~m}$ and the dry season usually lasts from November to March, with the water level fluctuating between 8 and $11 \mathrm{~m}$. The decrease in the water level leads to the exposure of large areas of fluctuating zones, providing suitable habitats for wintering waterbirds. 
Greater White-fronted Geese use three major habitats (meadows, mudflats, and paddy fields) when wintering at Shengjin Lake. Due to the periodic drawdowns of the lake, macrophytes such as Carex tristachya, are successively exposed in the bare substrates, and henceforth in the autumn and winter attract a large number of geese to forage (Xu et al. 2008; Yang 2011). The mudflats are thus defined as newly exposed fluctuating zones with vegetation coverage of $<30 \%$, while the meadows are fluctuating zones with vegetation coverage of $>30 \%$. The Carex on the fluctuating zones began to grow with the recession, with an average temperature of $17.5{ }^{\circ} \mathrm{C}$ from October to November, then the temperature dropped gradually. When the temperature started to rise in mid-February, the Carex began to grow again on the fluctuating zones (Zhao et al. 2012). Based on previous surveys and research, the leftover rice is known to grow into seedlings after the harvest in the paddy fields in November, attracting waterbirds (Zhou et al. 2010). This kind of habitat was lost though, because residents exploited the paddy fields for aquaculture from February each year, so we considered the paddy fields at middle stage as the important habitat. In recent years, with the degradation of wetlands and habitat loss (Yang et al. 2010; Zhang et al. 2018), there has been a sharp decline in the vegetation of fluctuating zones (Wang et al. 2015). The habitat availability has changed significantly, forcing wintering waterbirds to weigh between original foraging habitats and paddy fields, to obtain a sufficient amount of food (Zhao et al. 2012), so we have used meadows, mudflats, and paddy fields as sampling sites to collect behavior and food item data for the geese (Fig. 1).

\section{Food resources survey}

During the winter period from 2017 to 2018, we divided the wintering season (October 2017 to early April 2018) into three periods: early, from October to December; middle, from December to February; and late, from February to April, depending on the phenology and stable numbers of the Greater White-fronted Geese (Shimada et al. 2005). Based on relevant literature and field investigation, we divided the foraging habitats during the wintering season into three types: meadows, mudflats, and paddy fields. Nine quadrats were selected using a random sampling method in each sampling area every month. The area of each quadrat was $0.4 \mathrm{~m} \times 0.4 \mathrm{~m}$, and the height of the grass and local temperature were recorded, removing the samples taller than $14 \mathrm{~cm}$. In each quadrat, we collected all the aboveground plant material, and the samples were taken to the laboratory and dried at $60{ }^{\circ} \mathrm{C}$ in an oven (YHG-9050A; Derip, Suzhou, China), for a period of $72 \mathrm{~h}$ or less, to a constant weight, which represented the dry weight $(\mathrm{g})$. We defined the dry weight

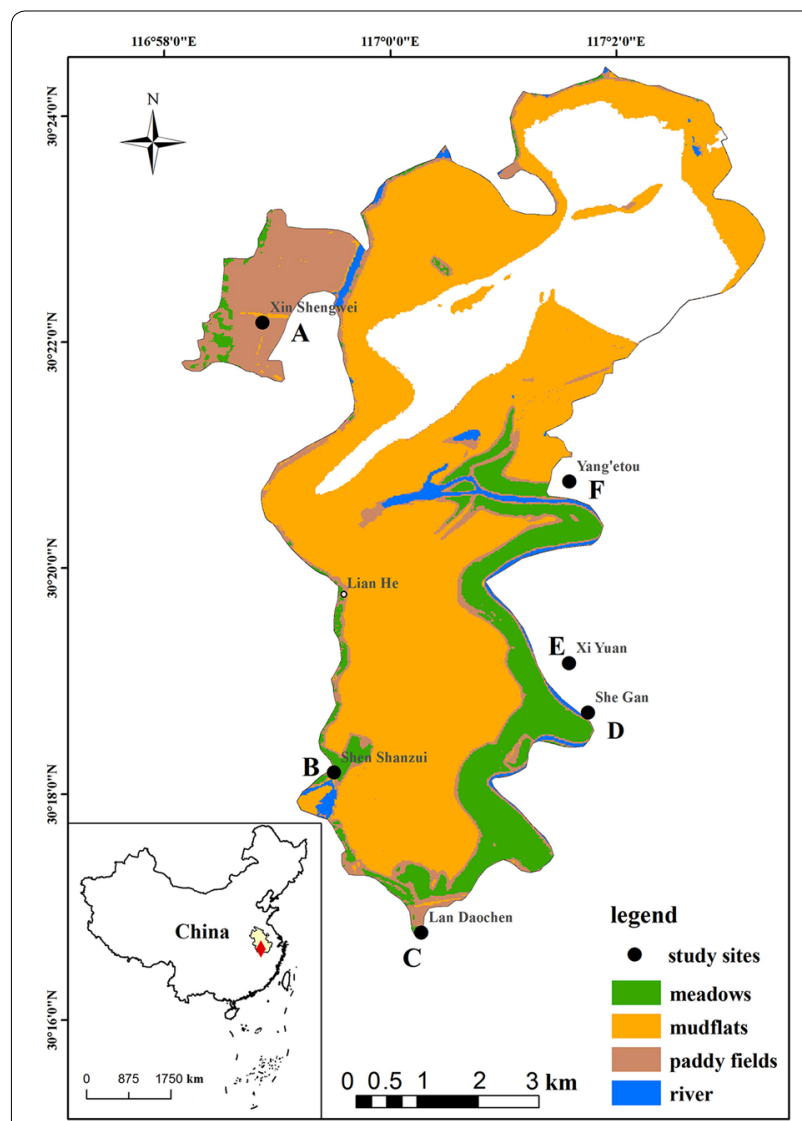

Fig. 1 Foraging habitats for the White-fronted Goose in the upper part of Shengjin Lake (A, B, C, D, E, and F indicate the study sites)

of the food items in a quadrat $\left(0.16 \mathrm{~m}^{2}\right)$ as food density $\left(\mathrm{g} / \mathrm{m}^{2}\right)$. In order to ensure the independence of the data samples, the distance between every two adjacent quadrats was $\geq 50 \mathrm{~m}$ (Jing et al. 2007).

\section{Bird survey}

Each day we used a direct counting method to survey the number of Greater White-fronted Geese. We began the survey at 7:00 in the morning each day. Once we found a group of geese, the entire visible site was scanned clockwise using a spotter telescope (Swarovski, $30 \times 60$ ). The number of foraging geese in each habitat was recorded. In order to reduce the effects of severe weather on our observations, the survey was postponed to the next day on days with strong winds, thick fogs, or heavy snows (Jia 2013).

\section{Behavior observations}

Behavior observations were carried out on sunny days from October 2017 to April 2018. Focal sampling was conducted with binoculars $(8 \times 42)$ and a telescope $(20$ $60 \times 63$ ) to record behavior from 07:00 to 17:00 (Yang 
2011). At the beginning of each focal observation, the date, time, location, and habitat type (paddy, meadow, or mudflat) were recorded. The object of the observations in each group was usually a single adult ( $\geq 3$ birds). All observations were taken from a relatively remote location, to avoid the presence of the investigators impacting the behavior of the geese (De Azevedo et al. 2010). A voice recorder (DVR-990, JNN) was used to record their vocal behavior for $20 \mathrm{~min}$, unless sight of the focal individuals was lost. Referring to Zhou et al. (2010), the ethogram comprised the following types of behavior: foraging, alert, social behaviors, moving, and resting. Obvious swallowing behavior was a sign of successful foraging. When the grass was over $14 \mathrm{~cm}$ high, it would cover the geese, and the relevant behaviors were difficult to observe, and these observations were abandoned.

\section{Data analysis}

The relative abundance of the geese in each habitat patch was estimated using the percentage of the number of geese in each habitat, as a proportion of the total number of geese in all habitats during a specific period (Jing et al. 2007; Gyimesi et al. 2012). We defined the ratio of the number of foraging individuals present in the habitat divided by the total number of individuals using the foraging habitat during the same period. Each sample was typically videotaped for about $20 \mathrm{~min}$. Video records shorter than $20 \mathrm{~min}$ were discarded in order to increase the data reliability and representativeness, as suggested in various studies (Zheng et al. 2015). The survey results from each 20 -min period were used as a behavior samples, from which we calculated the foraging rate (the number of pecks during a foraging bout) and activity time budget for foraging (Lafever 2006; De Azevedo et al. 2010; Li et al. 2013b). Foraging success was quantified by analyzing the recordings of the foraging geese and budgeting their time for foraging bouts (Kuwae et al. 2010). The Kruskal-Wallis $H$ test was used to determine the differences in food density and habitat use, and time budgets in the three habitats at the three stages of the wintering period, because the data is not normally distributed. In addition, the effect of the food resources during the three stages of winter and the habitat types, on foraging behavior (foraging time budget, foraging rate), were analyzed using a generalized linear regression model. Akaike's Information Criterion (AICc) adjusted for small sizes and Akaike weights $\left(w_{\mathrm{j}}\right)$ was used to evaluate the importance among the competing models (Akaike 1973). The minimum value of the AICc was considered the best model. The probability of various models was evaluated using the model weight $\left(w_{\mathrm{i}}\right)$ (Anderson. 2008), but when no single model was clearly superior, in comparison with the others $(\triangle \mathrm{AICc}>2)$, all candidate models must be model-averaging including the models of low Akaika weight (Symonds and Moussalli. 2011). Model-averaging estimates were used for the average of the parameter estimates or model predictions, based on the model of $95 \%$ confidence set, which started with the highest Akaike weight, and adding the model with the next highest weight, until the cumulative sum of the weights exceeded 0.95 (Symonds and Moussalli. 2011). All analyses were performed using SPSS Statistics 22 (IBM SPSS Inc., Chicago, IL, USA). A significance level of $0.05(P)$ was used for all statistical tests, with means expressed as mean $\pm \mathrm{SE}$.

\section{Results}

\section{Food density and habitat utilization}

During the early winter period, the food density was highest in the meadows $\left(295.64 \pm 46.07 \mathrm{~g} / \mathrm{m}^{2}, n=30\right)$, lower in the paddy fields $\left(110.17 \pm 32.40 \mathrm{~g} / \mathrm{m}^{2}, n=27\right)$, and lowest in the mudflats $\left(19.23 \pm 6.78 \mathrm{~g} / \mathrm{m}^{2}, n=27\right)$. During the middle of the winter period, the food density in the paddy fields decreased significantly $\left(45.22 \pm 20.57 \mathrm{~g} / \mathrm{m}^{2}, n=27\right)$, while the food density in the meadows increased significantly $\left(595.88 \pm 27.08 \mathrm{~g} / \mathrm{m}^{2}, n=27\right)$. During the late winter period, the food density decreased significantly in all three habitats (Table 1). Along with the temporal variations and the exploitation of the food resources, the food density varied widely among the three study sites. It was concluded that there was a gradual increase in food density followed by a decrease in the meadows while in the paddy fields and mudflats there was a gradual decrease in food density.

The maximum number of individuals we observed was 10,000 in the early winter, 18,500 in the middle of winter, and 12,000 in late winter, at the upper part of Shengjin Lake, and this showed the changing trends of the unimodal distribution. Utilization of foraging habitats by the Greater White-fronted Goose showed no significant differences over the three stages of the wintering period besides mudflats (Table 2). Over the whole winter period, the habitat utilization rate was the lowest in the paddy fields, with the meadow habitats being most utilized, followed by the mudflats. Furthermore, the utilization of

\begin{tabular}{|c|c|c|c|c|c|}
\hline \multirow{2}{*}{$\begin{array}{l}\text { Habitat } \\
\text { type }\end{array}$} & \multicolumn{3}{|c|}{ Food density $\left(\mathrm{g} / \mathrm{m}^{2}\right)$} & \multicolumn{2}{|c|}{ Statistical test } \\
\hline & Early winter & Middle winter & Late winter & $x^{2}$ & $P$ \\
\hline Mudflat & $19.23 \pm 6.78$ & $19.08 \pm 1.87$ & $12.21 \pm 5.10$ & 3.07 & 0.21 \\
\hline Meadow & $295.64 \pm 46.07$ & $595.88 \pm 27.08$ & $304.35 \pm 136.58$ & 5.98 & 0.05 \\
\hline Paddy field & $110.17 \pm 32.40$ & $45.22 \pm 20.57$ & $13.83 \pm 4.09$ & 8.02 & 0.018 \\
\hline
\end{tabular}

If $P>0.05$, then there was no statistically significant difference, according to the Kruskal-Wallis $H$ test 
Table 2 Foraging habitat uses of the geese over the three different stages of winter

\begin{tabular}{|c|c|c|c|c|c|}
\hline \multirow[t]{2}{*}{ Habitat types } & \multicolumn{3}{|c|}{ Foraging habitat uses (\%) } & \multicolumn{2}{|c|}{$\begin{array}{l}\text { Statistical } \\
\text { test }\end{array}$} \\
\hline & Early winter & $\begin{array}{l}\text { Middle } \\
\text { winter }\end{array}$ & Late winter & $x^{2}$ & $P$ \\
\hline Meadow & $53.21 \pm 9.21^{\mathrm{a}}$ & $51.91 \pm 6.85^{\mathrm{a}}$ & $56.04 \pm 12.06^{\mathrm{a}}$ & 2.18 & 0.118 \\
\hline Mudflat & $17.01 \pm 8.52^{\mathrm{a}}$ & $5.20 \pm 1.11^{\mathrm{ab}}$ & $2.15 \pm 2.17^{b}$ & 4.25 & 0.021 \\
\hline Paddy field & $1.01 \pm 0.45^{\mathrm{a}}$ & $15.21 \pm 4.33^{\mathrm{a}}$ & $2.12 \pm 1.04^{\mathrm{a}}$ & 1.98 & 0.214 \\
\hline
\end{tabular}

If two stages have the same lowercase letters, they were not statistically significantly different $(P>0.05)$, according to the Kruskal-Wallis $H$ test

the meadows showed a trend of bimodal distribution, the utilization of paddy fields showed a unimodal distribution trend, and the utilization of the mudflats showed a decreasing trend over the whole wintering period (Fig. 2).

\section{Activity time budget}

Foraging behavior accounted for the highest proportion of the geese throughout the wintering ethogram, including the early $(41.33 \pm 28.08 \%)$, middle $(29.09 \pm 17.44 \%)$, and late $(39.15 \pm 11.01 \%)$ periods, and there were no significant differences in the foraging during the three wintering stages (Table 3). The results of the $\mathrm{K}-\mathrm{W}$ test and multiple comparisons indicated that there were significant differences in the moving behaviors during the three different wintering periods. During the three winter stages, the geese spent most of their time foraging, and a lot of time moving $(6.21 \pm 3.01 \%, 10.25 \pm 8.01 \%$, and $29.00 \pm 10.14 \%$, for the early, middle, and late periods, respectively), and the geese spent the least amount time 'on alert' during the winter period (Table 3). During the winter period at Shengin Lake, the time devoted to foraging behavior increased gradually with the reduced food resources (Fig. 3). The geese spent the most time foraging in meadows, and the least time in the paddy fields (Table 2), but from early to middle winter, there was a significant increase in the use of paddy fields in the foraging time budget, compared with the other foraging
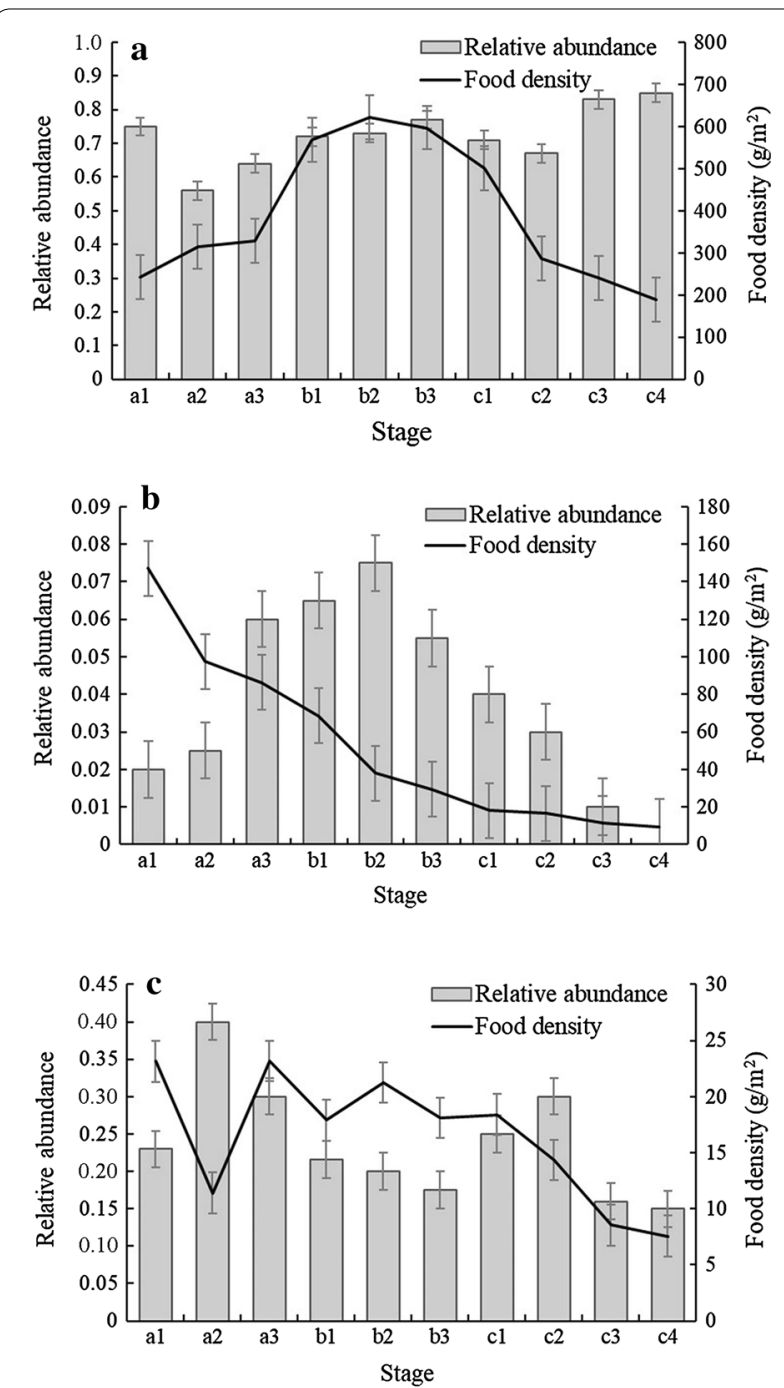

Fig. 2 The use of the habitat in each stage (a Meadow, $\mathbf{b}$ Paddy field, c Mudflat.; a1, a2, a3 early winter, b1, b2, b3 middle winter, c1, c2, c3, c4 late winter; the 1, 2, and 3 represent time series)

habitats (Table 2). There was no significant difference $(P=0.118$ and $P=0.214$, respectively) in the foraging

Table 3 Activity time budgets of the Greater White-fronted Goose in each of the three different stages of winter

\begin{tabular}{lccccc}
\hline Behavior types & \multicolumn{2}{l}{ Activity time budgets (\%) } & & \multicolumn{2}{c}{ Statistical test } \\
\cline { 2 - 5 } & Early winter & Middle winter & Late winter & & $\mathbf{X}^{\mathbf{2}}$ \\
\hline Foraging & $41.33 \pm 28.08^{\mathrm{a}}$ & $29.09 \pm 17.44^{\mathrm{a}}$ & $39.15 \pm 11.01^{\mathrm{a}}$ & 0.41 & $\boldsymbol{P}$ \\
Alert & $3.12 \pm 2.47^{\mathrm{a}}$ & $0.29 \pm 1.10^{\mathrm{a}}$ & $1.25 \pm 0.28^{\mathrm{a}}$ & 2.21 & 0.566 \\
Social behavior & $2.34 \pm 1.02^{\mathrm{b}}$ & $3.25 \pm 4.21^{\mathrm{a}}$ & $3.11 \pm 2.06^{\mathrm{a}}$ & 7.12 & 0.338 \\
Moving & $6.21 \pm 3.01^{\mathrm{c}}$ & $10.25 \pm 8.01^{\mathrm{b}}$ & $29.00 \pm 10.14^{\mathrm{a}}$ & 15.001 & 0.014 \\
Resting & $32.10 \pm 11.01^{\mathrm{a}}$ & $41.21 \pm 6.08^{\mathrm{a}}$ & $29.54 \pm 10.54^{\mathrm{a}}$ & 1.114 & 0.001 \\
\hline
\end{tabular}

If two stages have the same lowercase letter, they were not statistically significantly different $(P>0.05)$ according to the Kruskal-Wallis $H$ test 


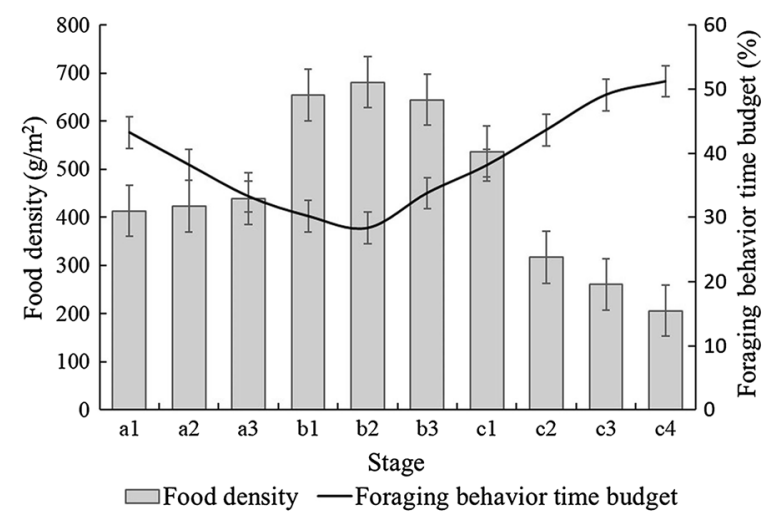

Fig. 3 The time budget of foraging behaviors related to the food density in each stage (a1, a2, a3 early winter, b1, b2, b3 middle winter, $c 1, c 2, c 3, c 4$ late winter)

time distribution between the meadow and paddy field (Table 2), while there was a significant difference with the

Table 4 Model-averaged coefficients estimates, standard errors (SE), and relative importance (RI) for the variables examined for all variables in the models

\begin{tabular}{llll}
\hline Variable & Estimate & SE & RI \\
\hline Food resource & 0.134282 & 0.002432 & 1.000 \\
Grass height & 0.054821 & 0.0001754 & 0.997 \\
Minimum temperature & 0.003324 & 0.000728 & 0.785 \\
Habitat area & 0.000192 & 0.000012 & 0.014 \\
Population size & 0.000476 & 0.000006 & 0.074
\end{tabular}

Table 5 Candidate linear regression models for predicting the wintering White-fronted Goose foraging rates

\begin{tabular}{lllll}
\hline Model & Lik & AICc & $\Delta$ AICc & $\boldsymbol{w}_{\mathbf{i}}$ \\
\hline Food resources + grass height & -1.47 & 14.25 & 0.00 & 0.41 \\
$\begin{array}{l}\text { Food resources + minimum tempera- } \\
\quad \text { ture + grass height }\end{array}$ & -2.56 & 16.34 & 1.24 & 0.11 \\
Food resources & -1.82 & 18.24 & 1.49 & 0.14 \\
Grass height & -4.31 & 21.12 & 2.34 & 0.16 \\
Grass height + minimum temperature & -3.21 & 24.52 & 3.21 & 0.08
\end{tabular}

Models with $\triangle \mathrm{AICC}>4.00$ are not shown $(n=11)$

mudflat habitat $(P=0.021)$ (Table 2).

\section{Foraging rate and influencing factors}

Based on univariate linear regression analysis, the grass height $\left(R^{2}=0.869, F=106.387, P=0.000\right)$ and food density $\left(R^{2}=0.550, F=19.585, P=0.000\right)$ were found to have a good degree of fitting with the foraging rate (Fig. 4). However, the average lowest temperature $\left(R^{2}=0.126\right.$,
$F=1.154, P=0.314)$ did not fit well with the regression of the foraging rate. We found that the food resources and grass height were the most important variables $(R I=1.000, R I=0.997)$ (Table 4$)$ and statistically significant (Table 5), so we obtained the optimal model (food resources + grass height) according to the AIC criteria. The result was the same as a single-factor linear regression analysis, indicating that the grass height and food density could explain the foraging behaviors of the wintering geese.

\section{Discussion}

\section{Effect of food resources on habitat use}

The quantity and quality of the food resources in the wetlands has become an indication of habitat quality (Coops et al. 2003; Wantzen et al. 2008; Steuer et al. 2015). During early wintering period, high density foods in the meadows attracted many Greater Whitefronted Geese to forage (Fig. 2), and due to man-made disturbances, only a small number of geese foraged in the paddy fields. As the aboveground Carex grass grew, secondary metabolites and cellulose gradually increased, and the protein content dropped, making the grass unpalatable. Winter rice matured in December, and fresh rice sprouts began to appear in the paddy field after the rice was harvested in the middle of the winter period (Fox and Abraham 2017). The geese had a preference for this kind of food, compared to the old Carex, and the paddy fields offered a far superior quality of foraging habitat and higher foraging rates than the natural mudflats and meadows, so some geese went to the paddy fields to forage (Fox and Abraham 2017). However, the year-round human activities in the buffer zone, that included the cultivating, harvesting, and daily routines, created high levels of interference that limited the use of the paddy field habitats, and thus there were only a few geese going to forage (Table 2). The rice sprouts then disappeared from the paddy fields because of the artificial water injections and rainwater in the late winter. At this time, Carex began to grow again on the lake beach, so some geese had to forage in the meadows and mudflats in the late winter period. Recently, due to early recessions and long dry seasons, the Carex habitats in the fluctuating zones at Shengjin Lake increased sharply, and the number of Greater White-fronted Geese foraging in the meadows has increased considerably. Although the meadows failed to provide sufficient food during certain periods, the geese have not yet given up this optimal foraging habitat. This was mainly because the meadows and mudflats provided a wider range of habitats. The foraging strategy for the seasonal changes, allows the geese to use the food resources over all of the wetlands, during the 

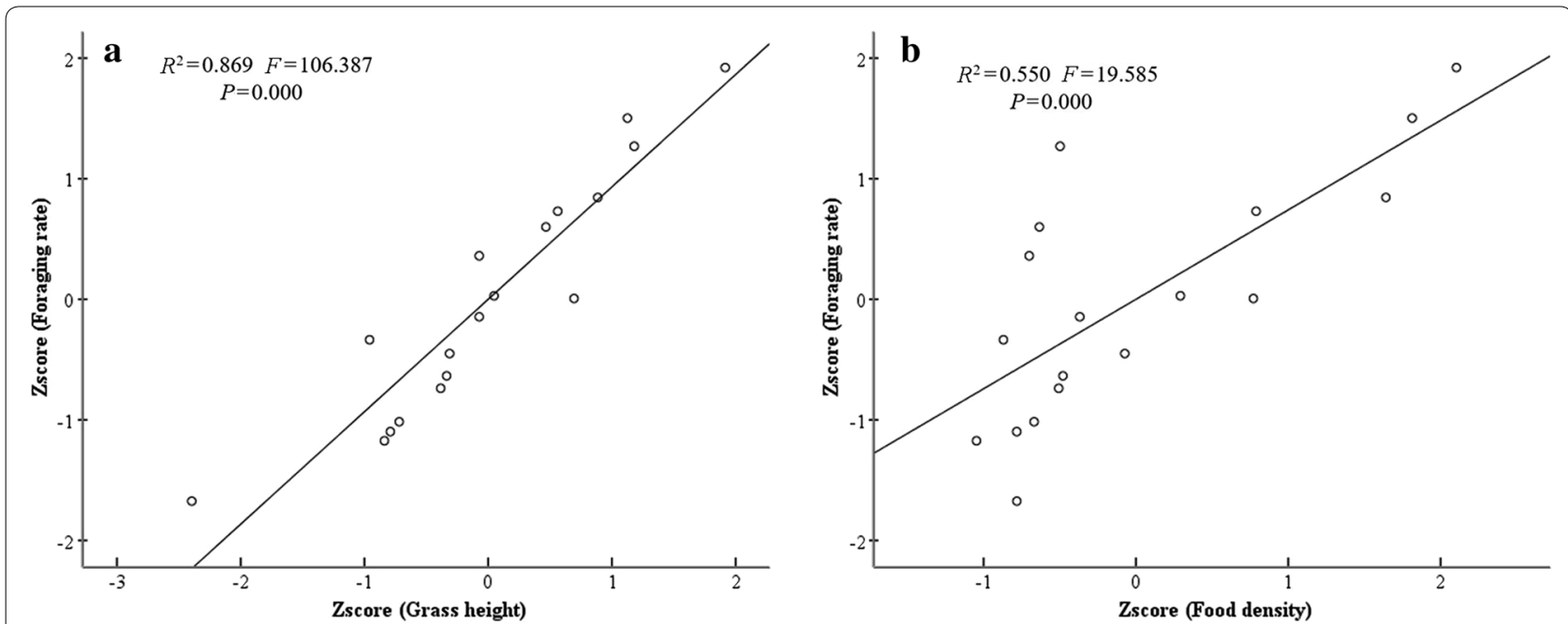

Fig. 4 Linear regression of the White-fronted Goose foraging rates correlated with $\mathbf{a}$ grass height, and $\mathbf{b}$ food density. Figures with black line showed independent variable has a significant effect on foraging rate $(P<0.05)$. Since the units of independent and dependent variables are not uniform, data normalization processing (Z-score), which is a numerical measurement of a value's relationship to the mean in a group of values, is carried out

course of the wintering period (Aharon-Rotman et al. 2017).

\section{Effect of food resources on activity time budgets}

In the early winter, the Greater White-fronted Goose needs plenty of food resources to make up for the energy loss in the process of migration and a large amount of time is consequently spent foraging in the meadows. In the middle of the winter period, the Carex entered the mature stage, with a low protein and high cellulose content, in order to make up the energy balance (Wang et al. 2014), and the geese moved to the paddy fields where they spent a large amount of time foraging. The time budget of the movement is related to the food resources in various habitats at Shengjin Lake (Fox et al. 1991). In the early stages of winter there were abundant food resources, so the geese spent less time searching for food. During the winter period, when the food resources were scarce, the geese would increase their foraging time budgets. The geese found risk in time through alerting, which is an important behavior of escape from danger (Long et al. 2009), but with decreased food resources, the geese would increase their time budget for foraging by reducing their alert time.

\section{Effect of key factors on the foraging rates of the White-fronted Goose}

If there was low food density conditions, the Whitefronted Geese at Shengjin Lake would change their foraging behaviors in response (Beerens et al. 2011). Our results indicated that in the early, middle, and late winter stages, there was a positive correlation between the foraging rates and the grass height, while Therkildsen and Madsen (2000) found that the foraging rate and the height of the grass had direct negative correlations with the Pink-footed Goose (Anser brachyrhynchus), within a certain height of the grass. As the geese need to bow their heads to peck, the shorter the Carex is, the more time they spend pecking (Van der Graaf et al. 2006). Based on the observed data, during the wintering period, the foraging rate of the geese would increase with increased grass height in a certain height range for the food density, and we found that the foraging rate of the geese had a positive correlation with the food density, Bautista et al. (1995) found that the foraging rates of the Common Crane (Grus grus) decreased with the availability of the food resources gradually and reduced over the whole winter period, and the pecking rate of the Greylag Geese (Anser anser) had decreased owing to the reduced food resources (Woog et al. 2012), which was consistent with our research results during the wintering stages. Due to the lack of the food resources in the middle winter stage and the need to migrate in late stage, the more abundant the food resources, the higher the foraging rates of the geese. For the minimum temperature, our results showed no correlation with the foraging rates. According to the Akaike information criterion, the optimal model was established, which further proved that the grass height and food density were the two most important factors influencing the foraging efficiency of the wintering Greater White-fronted Goose. 


\section{Conclusions}

The main habitat used by the Greater White-fronted Goose, shifted from the meadow to the paddy field, and then to the meadow, owing to the temporal-spatial changes of the food resources. The geese also increased their foraging rates if there was a shortage of food resources in any of the three habitats, during the winter period. Among the factors of grass height, food density, and temperature, we found that food density was the most important factor that influenced the foraging rates. When the food resources decreased, the geese would increase the allocation of foraging time correspondingly, to meet their energy demands during the overwintering period.

\section{Acknowledgements}

We thank the staff of Anhui Shengjin Lake National Nature Reserve for their help with the field work.

\section{Authors' contributions}

YF and LZ conceived and designed the experiments. YF performed the experiments, YF and LZ analyzed the data. LZ and LC contributed the materials/ analysis tools and YF and LZ wrote the paper. LZ liaised with reserve authorities and obtained province guidance and permission for the field work. YS and WX participated in the field work. All authors read and approved the final manuscript.

\section{Funding}

The work was supported by the National Natural Science Foundation of China (Grant No. 31472020).

\section{Availability of data and materials}

The data used and analyzed in this study are available from the corresponding authors on reasonable request.

\section{Ethics approval and consent to participate}

Not applicable.

\section{Consent for publication}

Not applicable.

\section{Competing interests}

The authors declare that they have no competing interests.

\begin{abstract}
Author details
${ }^{1}$ School of Resources and Environmental Engineering, Anhui University, Hefei 230601, China. ${ }^{2}$ Anhui Province Key Laboratory of Wetland Ecosystem Protection and Restoration (Anhui University), Hefei 230601, China. ${ }^{3}$ Anhui Shengjin Lake National Nature Reserve, Dongzhi 247200, China.
\end{abstract}

Received: 8 April 2019 Accepted: 15 January 2020

Published online: 05 February 2020

\section{References}

Aharon-Rotman Y, Mcevoy J, Zhaoju Z, Yu H, Wang X, Si Y, et al. Water level affects availability of optimal feeding habitats for threatened migratory waterbirds. Ecol Evol. 2017;7:10440-50.

Akaike $\mathrm{H}$. Information theory and an extension of the maximum likelihood principle. In: Petrov BN, Csaki F, editors. Proceeding of the 2nd international symposium on information theory. New York: Springer; 1973. p. 268-81.

Anderson DR. Model based inference in the life sciences: a primer on evidence. New York: Springer; 2008. p. 19-50.
Bautista LM, Alonso JC, Alonso JA. A field test of ideal free distribution in flockfeeding common cranes. J Anim Ecol. 1995;64:747-57.

Beerens JM, Gawlik DE, Herring G, Cook MI. Dynamic habitat selection by two wading bird species with divergent foraging strategies in a seasonally fluctuating wetland. Auk. 2011;128:651-62.

Cao L, Fox AD. Birds and people both depend on China's wetlands. Nature. 2009:460:173

Coops H, Beklioglu M, Crisman TL. The role of water-level fluctuations in shallow lake ecosystems-workshop conclusions. Hydrobiologia. 2003;506:23-7.

Durant D, Fritz H, Blais S, Duncan P. The functional response in three species of herbivorous Anatidae: effects of sward height, body mass and bill size. J Anim Ecol. 2003;72:220-31.

De Azevedo CS, Ferraz JB, Tinoco HP, Young RJ, Rodrigues M. Time-activity budget of greater rheas (Rhea americana, Aves) on a human-disturbed area: the role of habitat, time of the day, season and group size. Acta Ethol. 2010;13:109-17.

Faragó S, Hangya K. Effects of water level on water-bird abundance and diversity along the middle section of the Danube River. Hydrobiologia. 2012;697:15-21.

Fox AD, Abraham KF. Why geese benefit from the transition from natural vegetation to agriculture. Ambio. 2017;46:188-97.

Fox AD, Gitay H, Boyd H, Tomlinson C. Snow-patch foraging by pink-footed geese Anser brachyrhynchus in south Iceland. Ecography. 1991;14:81-4.

Fox AD, Hearn RD, Cao L, Cong PH, Wang X, Zhang Y, et al. Preliminary observations of diurnal feeding patterns of swan geese (Anser cygnoides) using two different habitats at Shengjin Lake, Anhui Province, China. Wildfowl. 2008;58:20-30.

Fox AD, Cao L, Zhang Y, Barter M, Zhao MJ, Meng FJ, et al. Declines in the tuber-feeding waterbird guild at Shengjin Lake National Nature Reserve, China-a barometer of submerged macrophyte collapse. Aquat Conserv. 2011;21:82-91.

Guan L, Wen L, Feng D, Zhang H, Lei G. Delayed flood recession in central Yangtze floodplains can cause significant food shortages for wintering geese: results of inundation experiment. Environ Manag. 2014;54:1331-41.

Gyimesi A, Franken MS, Feige N, Nolet BA. Human disturbance of Bewick's Swans is reflected in giving-up net energy intake rate, but not in givingup food density. Ibis. 2012;154:781-90.

Holm TE. Habitat use and activity patterns of Mute Swans at a molting and a wintering site in Denmark. Waterbirds. 2002;25:183-91.

Jia YF. Impact of water level fluctuation on Siberian Crane and other wintering waterbirds in Poyang Lake. Ph.D. thesis. Beijing: Beijing Forestry University; 2013 (in Chinese).

Jing K, Ma ZJ, Li B, Li JH, Chen JK. Foraging strategies involved in habitat use of shorebirds at the intertidal area of Chongming Dongtan, China. Ecol Res. 2007:22:559-70.

Jing L, Lu C, Xia Y, Shi L, Zuo A, Lei J, et al. Effects of hydrological regime on development of Carex wet meadows in East Dongting Lake, a Ramsar Wetland for wintering waterbirds. Sci Rep. 2017;7:41761.

Klaassen RHG, Nolet BA, Bankert D. Movement of foraging tundra swans explained by spatial pattern in cryptic food densities. Ecology. 2006;87:2244-54

Kuwae T, Miyoshi E, Sassa S, Watabe Y. Foraging mode shift in varying environmental conditions by dunlin Calidris alpina. Mar Ecol Prog Ser. 2010;406:281-9.

Lafever KE. Spatial and temporal winter territory use and behavioral responses of Whooping Cranes to human activities. Texas: Texas A\&M University; 2006.

Li D, Chen S, Lloyd H, Zhu S, Shan KAl, Zhang Z. The importance of artificial habitats to migratory waterbirds within a natural/artificial wetland mosaic, Yellow River Delta, China. Bird Conserv Int. 2013a;23:184-98.

Li ZQ, Wang Z, Ge C. Time budgets of wintering Red-crowned Cranes: effects of habitat, age and family size. Wetlands. 2013;33:227-32

Long S, Zhou C, Wang W, Pan L, Hu J. Diurnal behavioral rhythm, time budgets and group behavior of dwarf blue sheep in summer. Zool Res. 2009;30:687-93.

Maeda T. Patterns of bird abundance and habitat use in rice fields of the Kanto Plain, central Japan. Ecol Res. 2001;16:569-85. 
Maheswaran G, Rahmani AR. Effects of water level changes and wading bird abundance on the foraging behavior of black necked Ephippiorhynchus asiaticus in Dudwa National Park, India. J Biosci. 2001;26:373-82.

Nolet BA, Bevan RM, Klaassen M, Langevoord O, Van der Heijden YGJT. Habitat switching by Bewick's swans: maximization of average long-term energy gain? J Anim Ecol. 2002;71:979-93.

Owensmith N. How high ambient temperature affects the daily activity and foraging time of a subtropical ungulate, the greater kudu (Tragelaphus strepsiceros). J Zool. 2010;246:183-92.

Páez DJ, Restif O, Eby P, Plowright RK. Optimal foraging in seasonal environments: implications for residency of Australian flying foxes in food-subsidized urban landscapes. P Roy Soc B Biol Sci. 2018;373:20170097.

Pearse AT, Alisauskas RT, Krapu GL, Cox RR Jr. Changes in nutrient dynamics of midcontinent Greater White-fronted Geese during spring migration. J Wildlife Manag. 2011;75:1716-23.

Recher HF, Davis WE. Foraging behavior of mulga birds in Western Australia. I. Use of resources and temporal effects. Pacific Conserv Biol. 2018;24:74-86.

Shimada T. Daily activity pattern and habitat use of Greater White-fronted Geese wintering in Japan: factors of the population increase. Waterbirds. 2002;25:371-7.

Shimada T, Hatakeyama S, Miyabayashi Y, Kurechi M. Effects of climatic conditions on the northward expansion of the wintering range of the Greater White-fronted Goose in Japan. Ornithol Sci. 2005;4:155-9.

Steuer P, Hummel J, Grosse-Brinkhaus C, Südekum KH. Food intake rates of herbivorous mammals and birds and the influence of body mass. Eur J Wildlife Res. 2015;61:91-102

Symonds MRE, Moussalli A. A brief guide to model selection, multimodel inference and model averaging in behavioral ecology using Akaike's information criterion. Behav Ecol Sociobiol. 2011;65:13-21.

Therkildsen OR, Madsen J. Assessment of food intake rates in pink-footed geese Anser brachyrhynchus based on examination of oesophagus contents. Wildlife Biol. 2000;6:167-72.

Toral GM, David A, Bustamante J, Figuerola J. Using Landsat images to map habitat availability for waterbirds in rice fields. Ibis. 2011;153:684-94.

Van der Graff AJ, Coehoorn P, Stahl J. Sward height and bite size affect the functional response of barnacle geese Branta leucopsis. J Ornithol. 2006;147:479-84.

Wang X, Fox AD, Zhuang X, Cao L, Meng F, Cong P. Shifting to an energy-poor diet for nitrogen? Not the case for wintering herbivorous lesser whitefronted Geese in China. J Ornithol. 2014;155:707-12.

Wang L, Wang C, Deng DG, Zhao X, Zhou Z. Temporal and spatial variations in phytoplankton: correlations with environmental factors in Shengjin Lake, China. Environ Sci Pollut R. 2015;22:14144-56.
Wantzen KM, Rothhaupt KO, Mortl M, Cantonati M, László G, Fischer P. Ecological effects of water-level fluctuations in lakes: an urgent issue. Hydrobiologio. 2008;613:1-4.

Wilmshurst JF, Fryxell JM, Hudsonb RJ. Forage quality and patch choice by wapiti (Cervus elaphus). Behav Ecol. 1995;6:209-17.

Woog F, Schwarz K, Hulme M. All you can eat: do peck rates of Greylag Geese (Anser anser) vary with age and social status? J Ornithol. 2012;153:1025-9.

Xia SX, Liu Y, Chen B, Jia Y, Zhang H, Liu G, et al. Effect of water level fluctuations on wintering goose abundance in Poyang Lake wetlands of China. Chin Geogr Sci. 2017;27:248-58.

Xu LL, Xu WB, Sun QY, Zhou ZZ, Shen J, Zhao XX. Flora and vegetation in Shengjin Lake. Wuhan Bot Res. 2008;26:264-70 (in Chinese)

Yang XL. Research on the numbers, distribution, feeding behavior and diet of Great White-fronted Geese at Shengjin Lake, the national natural reserves in Anhui Province. Hefei: University of Science and Technology of China; 2011 (in Chinese).

Yang GS, Ma GH, Zhang L, Jiang JH, Yao SC, Zhang M, et al. Lake status, major problems and protection strategy in China. J Lake Sci. 2010;22:799-810 (in Chinese)

Zhao M, Cong P, Barter M, Fox AD, Cao LEI. The changing abundance and distribution of Greater White-fronted Geese Anser albifrons in the Yangtze River floodplain: impacts of recent hydrological changes. Bird Conserv Int. 2012;22:135-43.

Zhang XC, Qing HM, Jin BS, Chen JK, Wu JD, Liu GH, et al. Distribution in winter buds of submerged macrophyte and their contribution for herbivorous waterfowl in a shallow dish lake of Poyang Lake. Acta Ecol Sin. 2014;34:6589-96 (in Chinese).

Zhang DM, Zhou LZ, Song YW. Effect of water level fluctuations on temporal-spatial patterns of foraging activities by the wintering hooded crane (Grus monacha). Avian Res. 2015;6:16.

Zhang P, Zou Y, Xie Y, Zhang H, Liu X, Gao D, et al. Shifts in distribution of herbivorous geese relative to hydrological variation in East Dongting Lake wetland, China. Sci Total Environ. 2018;636:30-8.

Zheng M, Zhou L, Zhao N, Xu W. Effects of variation in food resources on foraging habitat use by wintering Hooded cranes (Grus monacha). Avian Res. 2015;6:11.

Zhou B, Zhou LZ, Chen JY, Cheng YQ, Xu WB. Diurnal time-activity budgets of wintering Hooded cranes (Grus monacha) in Shengjin Lake, China. Waterbirds. 2010;33:110-5.
Ready to submit your research? Choose BMC and benefit from:

- fast, convenient online submission

- thorough peer review by experienced researchers in your field

- rapid publication on acceptance

- support for research data, including large and complex data types

- gold Open Access which fosters wider collaboration and increased citations

- maximum visibility for your research: over $100 \mathrm{M}$ website views per year

At BMC, research is always in progress.

Learn more biomedcentral.com/submissions 